\title{
Guide to extracts from District Court field notes and interviews
}

Chapters 2, 4 and 5 are based directly on interviews and ethnographic research carried out in a number of Irish District Courts in 2009 and 2010 (Appendix A (Methodology); Appendix B (Participants)). All citations are from interviews or court observations.

\section{Interviews}

The eighteen interviewees are anonymised as follows:

Interpreters: Svetlana, Anna, Marta, Mihai, Belén, Molly, Stella, Jevgenius and Ewa

Barristers: Aoife, Eleanor and James

Solicitors: Matthew, Gerard, Thomas, Gwen, Stephen and Mark

\section{District Court field notes}

The courts and judges are referred to as follows.

The first, a Dublin city centre criminal court, is called City Centre Court and is abbreviated as ' $\mathrm{CitC}$ '. The relevant judges from this court are anonymised as $\mathrm{N}, \mathrm{R}, \mathrm{T}, \mathrm{U}, \mathrm{V}, \mathrm{W}$ and $\mathrm{X}$.

The second, a custody court outside Dublin city centre, is called Custody Court and is abbreviated as 'CusC'. The relevant judges from this court are anonymised as $\mathrm{O}, \mathrm{P}, \mathrm{Q}$ and $\mathrm{S}$.

The third, a set of three courts in medium to large towns outside of Dublin between which the same judge moves on different days, is collectively called Rural Court and is abbreviated as 'RC'. The relevant judges from this court are anonymised as $\mathrm{Y}$ and $\mathrm{Z}$.

Where standard or common phrases and terms are quoted, the court/ judge is not distinguished. Notes, quotations and dialogue from court were recorded by hand during proceedings and are not taken from transcripts. Text which represents the essence of what was said, rather 
than being a verbatim (or as close to that as possible) transcription, is denoted by square brackets.

In the course of observations for this study, oaths rather than affirmations were observed, such that the term 'oath' is used here throughout. However, there are undoubtedly circumstances in court where an affirmation rather than an oath is administered. 
Kate Waterhouse - 9781847799395 Downloaded from manchesterhive.com at $04 / 26 / 2023$ 02:43:49PM via free access 